\title{
Factors associated with smoking contemplation and maintenance among Iranian adolescents
}

Hamidreza Roohafza, ${ }^{1}$ Razieh Omidi, ${ }^{2}$ Tahereh Alinia, ${ }^{3}$ Kamal Heidari, ${ }^{2}$ Gholamhossein Mohammad-Shafiee, ${ }^{4}$ Morid Jaberifar, ${ }^{2}$ Masoumeh Sadeghi ${ }^{5}$ and Wasim Maziak ${ }^{6}$

${ }^{1}$ Isfahan Cardiovascular Research Center, Cardiovascular Research Institute, Isfahan University of Medical Sciences, Isfahan, Islamic Republic of Iran. ${ }^{2}$ Isfahan Province Health Center, Isfahan University of Medical Sciences, Isfahan, Islamic Republic of Iran. ${ }^{3}$ Student Research Committee, Department of Epidemiology, Shahid Beheshti University of Medical Sciences, Tehran, Islamic Republic of Iran (Correspondence to: T. Alinia: alinia_t@yahoo.com). ${ }^{4}$ Health Education and Wellness Office, Education Institute, Isfahan, Islamic Republic of Iran. ${ }^{5}$ Cardiac Rehabilitation Research Center, Cardiovascular Research Institute, Isfahan University of Medical Sciences, Isfahan, Islamic Republic of Iran. ${ }^{6}$ Robert Stempel College of Public Health and Social Work, Florida International University, Miami, Florida, United States of America.

\begin{abstract}
Background: Evidence is scarce on which factors contribute to cigarette and waterpipe contemplation and no previous study has examined the factors associated with waterpipe maintenance.

Aims: This study aimed to determine the factors associated with cigarette and waterpipe smoking contemplation and maintenance among Iranian adolescents.

Methods: Factors including depression, risky behaviour, family conflict, attitude to smoking acceptability and self-efficacy were examined using a questionnaire for 5500 adolescents at the smoking contemplation or maintenance stage.

Results: Students with depression had nearly double the chance [95\% confidence interval (CI): 1.41-2.72] of cigarette smoking contemplation. Risk takers had odds of 2.13 (95\% CI: 1.51-2.94) and 1.49 (1.22-1.85) of cigarette and waterpipe (hookah) smoking contemplation, respectively. Those facing family conflict had odds of 1.87 ( $95 \%$ CI: 1.38-2.53) and 1.53 for cigarette and waterpipe smoking contemplation, respectively. The contemplation odds for students with more positive attitude to smoking acceptability were 2.12 (95\% CI: 1.51-2.97) and 1.72 for cigarette and waterpipe smoking, respectively. Higher self-efficacy was associated with lower cigarette and waterpipe smoking contemplation. Risky behaviour was related to smoking maintenance. A more positive attitude to smoking acceptability was related to higher waterpipe maintenance (odds ratio $=1.57$ 95\% CI: 1.03-2.40).
\end{abstract}

Conclusions: Depression, attitude to smoking acceptability and risky behaviour are factors associated with smoking contemplation and maintenance.

Keywords: adolescent, contemplation, maintenance, smoking.

Citation: Roohafza H; Omidi R; Alinia T; Heidari K; Mohammad-Shafiee G; Jaberifar M; et al. Factors associated with smoking contemplation and maintenance among Iranian adolescents. East Mediterr Health J. 2018;24(8):714-721. https://doi.org/10.26719/2018.24.8.714

Received: 28/06/16; accepted: 12/06/17

Copyright (c) World Health Organization (WHO) 2018. Some rights reserved. This work is available under the CC BY-NC-SA 3.0 IGO license (https:// creativecommons.org/licenses/by-nc-sa/3.o/igo).

\section{Introduction}

The transtheoretical model is a basis to explain people's smoking behaviour. It claims that individuals go through a series of stages to adopt lifetime smoking. The sequences begin with the precontemplation stage, followed by contemplation, preparation and action stages, and then they reach the maintenance stage. According to the transtheoretical model, people generally pass each stage to move to the next one. Preventing adolescents from moving forward at each stage will inhibit their progression to the next stage and regular, maintained smoking.

Contemplation is characterized by a cognitive predisposition or lack of a resolute commitment to remain smoke free $(1,2)$. It has robust predictive ability in smoking initiation. Adolescents in the contemplation stage have 2-3 times higher likelihood of cigarette smoking during the following 2 years in comparison to those out of this stage (3). A study in California, United States of America reported a high transition rate among students in the contemplation stage to the maintenance stage (4). Those at the maintenance stage were able to sustain smoking and incorporate it into their daily lives.

Several factors are associated with adolescents' smoking, including familial and psychological factors (5). Depressive symptoms lead to an increased chance of smoking contemplation and maintenance (6). Selfefficacy reflects confidence in the ability to exert control over one's own motivation, behaviour and social environment. Self-efficacy has been postulated to change behaviour (7) and it is protective against smoking initiation (8). A study in Turkey showed that higher selfefficacy levels accompany higher negative perceptions about the disadvantages of smoking (9). A longitudinal study revealed that adolescents with risky behaviour are at higher risk of behavioural problems at school (10). No previous study has determined which factors contribute to cigarette and waterpipe smoking contemplation, except a study in the Islamic Republic of Iran that showed different influential factors for initiation of cigarette compared to waterpipe (hookah) smoking (11). There is a 
lack of studies about why students maintain waterpipe smoking.

Guided by the transtheoretical model, we explored the effect of familial and psychological factors on smoking contemplation and maintenance. Our results could provide invaluable information on factors that trigger cigarette and waterpipe smoking contemplation and maintenance among adolescents. This may help public health practitioners and policy-makers to develop new strategies to reduce students' susceptibility and prevent them from starting smoking.

\section{Methods}

\section{Study design}

Data were extracted from a cross-sectional survey titled the Isfahan Tobacco Use Prevention Program. This study was conducted among students (grade 6-12) in Isfahan Province (the second most populated province of the Islamic Republic of Iran). The students were aged 11-19 years.

To obtain the correct sample size using Formula 1, smoking prevalence was considered to be $14 \%$ based on a study among students in 2003 (2), with 95\% confidence interval (CI) and 0.01 margin of error. After considering attrition due to not answering or incomplete answering (defined as $>10 \%$ of questionnaire items left blank), we estimated the sample size as 5500.

$$
\text { Formula } 1 \mathrm{n}=\frac{0.14 \times 0.86 \times(1.96)^{2}}{(0.01)^{2}}
$$

Students were selected using multistage stratified cluster random sampling. Educational districts were considered as clusters. Stratified sampling was based on the school level (high or middle), gender and area of residence (rural or urban) within each cluster. Schools were selected randomly from among each cluster, and finally, students were selected from each selected school using a random number table. The students gave signed consent for participation in the study and answered the questionnaires in a 30-minute period during class time. A total of 5408 questionnaires were completed and returned, with a $98.3 \%$ response rate. The study was approved by Ethics Committee of Isfahan University of Medical Science.

\section{Background information}

A self-administered anonymous questionnaire elicited demographic data and parental variables, including age, sex, education level and smoking status. Students were considered to be never-smokers if they had not smoked even a single puff; otherwise, they were classified as smokers.

\section{Smolking contemplation and maintenance}

To assess smoking contemplation, we assessed the adolescents' intention toward future smoking. Never-smok- ers answered the question, "Is there a possibility that you will smoke in the future?" A similar question was asked about smokers as well, "Is there a possibility that you will maintain smoking in the future?" Those with a yes response to the first question were in the smoking contemplation stage and the latter group were in the smoking maintenance stage. Contemplation and maintenance were separately determined for cigarette and waterpipe smoking.

\section{Risk factors}

The participants completed a 13-item depression subscale of the Symptom Checklist-90-R (SCL-90), by rating items on how they felt in the past 4 weeks (12). The possible total score ranged from o to 13 (Cronbach's $\alpha=0.88$ ). Risky behaviour was measured on a 3-item scale, with scores ranging from o to 15 points: (1) "It is worth getting into trouble for fun"; (2) "I like risk taking"; and (3) "I enjoy doing things that people believe should not be done". The items were scored on a 5-point Likert scale from $1=$ not at all, to $5=$ always. Cronbach's $\alpha$ was 0.71 . Family conflict was measured as the sum score of a 3-item scale: (1) "My parents nag me for any excuse"; (2) "My family does not understand me"; and (3) "I have a lot of arguments with my family". The students answered each item yes or no, which scored 1 and 0 , respectively. The scale ranged from o to 3 (Cronbach's $\alpha=0.73$ ). Attitude to smoking acceptability was assessed via 9 items, using a 2-point response (agree or disagree). Items were: (1) "Sometimes, you feel you need to smoke a cigarette or even have a puff of waterpipe"; (2) "Smoking is too expensive"; (3) Children are more likely to smoke if their parents smoke; (4) "Students should be allowed to smoke cigarettes"; (5) "Sometimes, you like to show up as a smoker"; (6) "Smoking is something you do when other people want you to do it"; (7) "Smoking makes you feel grown up"; (8) "Smoking is hazardous to nonsmokers' health"; and (9) "Students should be allowed to smoke a waterpipe". Items 2 and 8 were scored reversely. The scores ranged from o to 9 (Cronbach's $\alpha=0.79$ ). To determine self-efficacy, the participants were asked 10 questions from the General Self-Efficacy Scale, with responses rated from o (not at all) to 3 (very true). Scores ranged from o to 30. General self-efficacy has been demonstrated to possess good reliability (Cronbach's $\alpha=0.86)$. It was then categorized into three levels $<15,15-25$ and $>25$ that indicated low, moderate and high self-efficacy, respectively.

Higher scores showed a higher level for all the risk factors. All questionnaires were investigator invented except for depression and self-efficacy. Before the final version of the questionnaire was adopted for use in the present study, a pilot study was conducted and the questionnaires were administered to a group of 30 students to assess their reliability and face validity. The validity index was appropriate. Cronbach's $\alpha$ was 0.73 for family conflict, 0.71 for risky behaviour, 0.88 for depression, 0.86 for self-efficacy and 0.86 for smoking attitude. The risk factors, except self-efficacy, were categorized into 2 categories by their median. 


\section{Data analysis}

The relationships between the covariates depression, risky behaviour, family conflict, attitude to smoking acceptability, perceived self-efficacy, and smoking contemplation and maintenance were analysed using univariate logistic regression. Logistic regression was adjusted for age, sex, parental education and parental smoking. Odds ratio (OR) and its $95 \% \mathrm{CI}$ were reported. $\mathrm{P}<0.05$ was considered to be statistically significant. All analyses were performed with SPSS version 15.

\section{Results}

Regarding cigarette smoking, out of 5365 students who completely answered the questionnaire, there were 4427 $(82.5 \%)$ never-smokers and 935 (17.5\%) ever-smokers; 87 $(2.0 \%)$ of the never-smokers were at the contemplation stage and $212(22.7 \%)$ of the ever-smokers were at the maintenance stage. For waterpipe smoking, there were $3631(67.7 \%)$ never-smokers and 1728 (32.3\%) ever-smokers. There were $174(4.8 \%)$ students at the contemplation stage and $702(40.6 \%)$ students at the maintenance stage.

Table 1 shows univariate regression analysis of the predisposing factors for smoking contemplation. Students with highly educated parents had higher odds of cigarette and waterpipe smoking contemplation. Male gender, parental smoking, depression, risky behaviour, family conflict, and more positive attitude to smoking acceptability were directly associated with cigarette and waterpipe smoking contemplation; self-efficacy was inversely related to cigarette and waterpipe smoking contemplation. Risky behaviour was the strongest underlying factor for both cigarette and waterpipe smoking contemplation. Students with risky behaviour had an OR of 5.95 (95\% CI: 4.54-7.75) of cigarette smoking contemplation and were 3.44 times (95\% CI:2.96-4.0) more likely to be at the waterpipe contemplation stage. The OR of smoking contemplation for students with higher selfefficacy was 0.38 (95\% CI: 0.26-0.55) for cigarette and 0.56 (95\% CI: 0.45-0.70) for waterpipe smoking.

Table 2 shows univariate logistic regression analysis of the covariates of cigarette and waterpipe smoking maintenance. The predisposing factors were different. Paternal education was associated with increased odds of cigarette smoking maintenance. Paternal smoking raised the likelihood of cigarette smoking maintenance. Risky behaviour and positive attitude to smoking acceptability elevated smoking maintenance odds by 2.14 (95\% CI: 1.523.01) and 1.41 (95\% CI: 1.01-1.98) times, respectively. The higher the parental education attainment was, the higher the probability of waterpipe smoking maintenance was among ever-smokers. Students who had parents that smoked had a $100 \%$ excess risk of waterpipe smoking maintenance ( $\mathrm{OR}=2.0$, 95\% CI: 1.26-3.17); risky behaviour heightened waterpipe smoking maintenance by 4.17 times (95\% CI: 2.32-7.48).

Adjusted ORs are shown in Table 3. Cigarette smoking contemplation among never-smokers nearly doubled $(\mathrm{OR}=1.96 ; 95 \% \mathrm{CI}$ : 1.41-2.72) for students with depression.
For risky behaviour, contemplation increased by 2.13 (95\% CI: $1.51-2.94)$ times for cigarette and by 1.49 (95\% CI: 1.22-1.85) for waterpipe smoking. For family conflict, contemplation increased by 1.87 (95\% CI: 1.38-2.53) times for cigarette and by 1.53 (95\% CI: 1.24-1.88) times for waterpipe smoking. For more positive attitude to smoking acceptability, contemplation increased by $2.12(95 \% \mathrm{CI}$ : 1.51-2.97) times for cigarette and by 1.72 (95\% CI: 1.412.10) times for waterpipe smoking. Higher self-efficacy protected adolescents against cigarette and waterpipe smoking contemplation. Risky behaviour significantly contributed to smoking maintenance $(\mathrm{OR}=3.70 ; 95 \% \mathrm{CI}$ : 1.85-7.14 for cigarettes; OR $=1.89$; 95\% CI: $1.33-3.03$ for waterpipe). Attitude to smoking acceptability was linked to waterpipe smoking maintenance $(\mathrm{OR}=1.57 ; 95 \% \mathrm{CI}$ : 1.03-2.40).

\section{Discussion}

The present study explored the effect of familial and psychological factors on smoking contemplation and maintenance. Risky behaviour, family conflict, more positive attitude to smoking acceptability and lower self-efficacy were associated with cigarette smoking contemplation. Depression was only associated with cigarette smoking contemplation. Risky behaviour was the only factor contributing to cigarette smoking maintenance, and this, along with positive attitude to smoking acceptability, was linked to waterpipe smoking maintenance.

The present research showed that boys were more vulnerable than girls to cigarette and waterpipe smoking contemplation. Adolescents of parents who smoked were more likely to contemplate and maintain smoking behaviour. Parental smoking affects adolescent belief that smoking is acceptable and it is a norm; students who have smoker parents also have greater accessibility to smoking and indulge in behaviour imitation (13).

Psychological factors of intention to future smoking, including depression and self-efficacy, worked at the contemplation stage; however, they were not associated with smoking maintenance. Current literature agrees with the detected association between depression and cigarette smoking contemplation $(6,14)$. A longitudinal study reported that ever-smokers with depression progressed to daily smoking after 5 years; however, we could not find such an association, maybe because of the different age range in our sample (15). Psychological factors that influence cigarette smoking contemplation are of less importance for waterpipe smoking contemplation (11). A recent study in the Islamic Republic of Iran found that psychological factors such as coping with stress trigger students to start cigarette smoking, while entertainment factors are more likely reasons for waterpipe than cigarette smoking initiation (11). Selfefficacy protected students from cigarette smoking contemplation, which agreed with earlier studies (16). However, self-efficacy has an effect at an early stage of smoking behaviour adaptation, and biological factors such as physical or mental dependence or peer pressure are prominent for smoking maintenance (17). 


\begin{tabular}{|c|c|c|c|c|c|c|}
\hline & \multicolumn{3}{|c|}{ Cigarette contemplation } & \multicolumn{3}{|c|}{ Waterpipe contemplation } \\
\hline & No & Yes & OR $(95 \% \mathrm{CI})$ & No & Yes & OR $(95 \% \mathrm{CI})$ \\
\hline \multicolumn{7}{|l|}{ Sex } \\
\hline Female & $2620(97.4)$ & $70(2.6)$ & 1 & $2405(89.5)$ & $282(10.5)$ & 1 \\
\hline Male & $2456(91.4)$ & $230(8.6)$ & $3.49(2.88-4.60)$ & $2090(77.8)$ & $596(22.2)$ & $2.43(2.08-2.78)$ \\
\hline \multicolumn{7}{|c|}{ Maternal education, yr } \\
\hline $0-5$ & 2268 (94.9) & $123(5.1)$ & 1 & 2049 (85.7) & $343(14.3)$ & 1 \\
\hline $6-12$ & $1856(95.1)$ & $97(4.9)$ & $0.83(0.92-1.85)$ & $1608(82.6)$ & $340(17.4)$ & $1.06(0.86-1.31)$ \\
\hline$>12$ & $754(92.3)$ & $63(7.7)$ & $1.59(1.14-2.21)$ & $670(81.6)$ & $151(18.4)$ & $1.34(1.09-1.66)$ \\
\hline \multicolumn{7}{|c|}{ Paternal education, yr } \\
\hline $0-5$ & 1799 (94.4) & $106(5.6)$ & 1 & $1640(86.0)$ & $267(14.0)$ & 1 \\
\hline $6-12$ & $2025(95.5)$ & $95(4.5)$ & $0.86(0.93-1.70)$ & $1761(83.3)$ & $353(16.7)$ & $1.17(0.97-1.41)$ \\
\hline$>12$ & $1040(93.1)$ & $78(6.9)$ & $1.59(1.16-2.15)$ & $907(81.0)$ & $213(19.0)$ & $1.44(1.18-1.75)$ \\
\hline \multicolumn{7}{|l|}{ Parental smoking } \\
\hline No & $2435(95.8)$ & $150(4.2)$ & 1 & $3126(87.1)$ & $461(12.9)$ & 1 \\
\hline Yes & $1625(91.6)$ & $149(8.4)$ & $2.10(1.66-2.65)$ & 1354 (76.5) & $415(23.5)$ & $2.07(1.79-2.40)$ \\
\hline \multicolumn{7}{|l|}{ Depression } \\
\hline Low & 2696 (96.7) & $93(3.3)$ & 1 & $2404(86.5)$ & $376(13.5)$ & 1 \\
\hline High & $2172(91.7)$ & $196(8.3)$ & $2.61(2.03-3.37)$ & $1903(80.2)$ & $470(19.8)$ & $1.57(1.36-1.83)$ \\
\hline \multicolumn{7}{|l|}{ Risky behaviour } \\
\hline Low & $3411(97.8)$ & $78(2.2)$ & 1 & $3130(89.8)$ & $357(10.2)$ & 1 \\
\hline High & $1561(88.0)$ & $212(12.0)$ & $5.95(4.54-7.75)$ & $1272(71.8)$ & $500(28.2)$ & $3.44(2.96-4.0)$ \\
\hline \multicolumn{7}{|l|}{ Family conflict } \\
\hline Low & 2298 (97.3) & $63(2.7)$ & 1 & 2102 (89.0) & 259(11.0) & 1 \\
\hline High & 2728 (91.0) & $269(9.0)$ & $3.51(2.71-4.56)$ & $2305(76.9)$ & $692(23.1)$ & $2.43(2.09-2.82)$ \\
\hline \multicolumn{7}{|l|}{ Smoking attitude } \\
\hline More positive & $2810(97.7)$ & $66(2.3)$ & 1 & $2573(89.6)$ & $300(10.4)$ & 1 \\
\hline Less positive & $2133(90.5)$ & $224(9.5)$ & $4.47(3.37-5.91)$ & 1798 (76.3) & $557(23.7)$ & $2.65(2.28-3.09)$ \\
\hline \multicolumn{7}{|l|}{ Self-efficacy } \\
\hline Low & 1275 (90.9) & $127(9.1)$ & 1 & $1112(79.4)$ & $289(20.6)$ & 1 \\
\hline Medium & $2413(95.5)$ & $113(4.5)$ & $0.80(0.55-1.18)$ & $2146(85.0)$ & $379(15.0)$ & $0.83(0.67-1.03)$ \\
\hline High & $977(96.4)$ & $37(3.6)$ & $0.38(0.26-0.55)$ & $886(87.2)$ & $130(12.8)$ & $0.56(0.45-0.70)$ \\
\hline
\end{tabular}

$C I=$ confidence interval; $O R=$ odds ratio.

Bold numbers with $P<0.05$.

Students with family conflict were more likely to contemplate cigarette and waterpipe smoking. Strong family bonds and parental support decrease smoking contemplation (18). Conflicts can result as adolescents pull away from their parents and spend more time with friends, and this increases the risk of peer behaviour imitation (19).

Consistent with previous studies, adolescents with more positive attitude to smoking acceptability are more likely to have a higher risk of cigarette and waterpipe smoking contemplation (20). Students with more positive attitudes to smoking acceptability had greater odds of waterpipe smoking maintenance. Students' understanding of the outside world and past experiences shape their attitude to smoking acceptability and determine their future behavioural choices. Social norms and peers may dramatically change students' attitude to smoking acceptability and smoking orientation (21).

Risky behaviour was a predisposing factor for both contemplation and maintenance of cigarette and waterpipe smoking, and our findings are in accordance with previous studies (10). Different forms of risky behaviour coexist and frequently interact and reinforce one another, according to the covariation and clustering theory (22). Cigarette smoking is considered to be a risky behaviour on its own, and cigarette smokers are more likely to commit other forms of risky behaviour (23). The underlying mechanism of engagement in risky behaviour probably lies in the adolescents' social life that provides opportunities for learning risky behaviour from their peers (24). Furthermore, some forms of risky behaviour serve as a way of affirming independence from parents (24). The strength of the association between risky behaviour and waterpipe smoking contemplation and maintenance was weaker than for cigarette smoking. This may be due to a lower cultural taboo of waterpipe compared with cigarette smoking and its accessibility (25). Therefore, those who start or continue waterpipe smoking are not necessarily those with higher-risk behaviour. In a survey of Lebanese adolescents, cigarette smoking was associated with a range of other risky behaviours, whereas waterpipe smoking was only associated with problem drinking (26).

This present large-scale study provides invaluable information about the factors that trigger smoking contemplation and maintenance among adolescents. 


\begin{tabular}{|c|c|c|c|c|c|c|}
\hline & \multicolumn{3}{|c|}{ Cigarette maintenance } & \multicolumn{3}{|c|}{ Water pipe maintenance } \\
\hline & No & Yes & OR $(95 \% \mathrm{CI})$ & No & Yes & OR $(95 \% \mathrm{CI})$ \\
\hline \multicolumn{7}{|l|}{ Sex } \\
\hline Female & $43(36.8)$ & $74(63.2)$ & 1.0 & $29(56.9)$ & $22(43.1)$ & 1.0 \\
\hline Male & $190(37.9)$ & $311(62.1)$ & $1.05(0.69-1.59)$ & $149(57.8)$ & $109(42.2)$ & $1.03(0.56-1.90)$ \\
\hline \multicolumn{7}{|l|}{ Maternal education, yr } \\
\hline $0-5$ & $117(44.2)$ & $148(55.8)$ & 1.0 & $89(64.5)$ & $49(35.5)$ & 1.0 \\
\hline $6-12$ & $75(33.5)$ & $149(66.5)$ & $1.25(0.60-1.67)$ & $60(60.0)$ & $40(40.0)$ & $2.85(1.49-5.46)$ \\
\hline$>12$ & $32(33.3)$ & $64(66.7)$ & $1.58(0.97-2.57)$ & $21(38.9)$ & $33(61.1)$ & $2.35(1.19-4.65)$ \\
\hline Paternal education, yr & & & 1.0 & $76(64.4)$ & $42(35.6)$ & 1.0 \\
\hline $0-5$ & $98(46.7)$ & $112(53.3)$ & $1.79(1.10-2.91)$ & $60(60.0)$ & $40(40.0)$ & $1.95(1.04-3.62)$ \\
\hline $6-12$ & $88(36.4)$ & $154(63.6)$ & & & & \\
\hline$>12$ & $30(24.2)$ & $94(75.8)$ & $2.74(1.67-4.48)$ & $30(43.5)$ & $39(56.5)$ & $2.35(1.28-4.38)$ \\
\hline \multicolumn{7}{|l|}{ Parental smoking } \\
\hline No & $133(41.7)$ & $186(58.3)$ & 1.0 & $115(64.6)$ & $63(35.4)$ & 1.0 \\
\hline Yes & $100(33.5)$ & $198(66.4)$ & $1.41(1.02-1.96)$ & $62(47.7)$ & $68(52.3)$ & $2.0(1.26-3.17)$ \\
\hline \multicolumn{7}{|l|}{ Depression } \\
\hline Low & $123(38.6)$ & $196(61.4)$ & 1.0 & $77(63.1)$ & $45(36.9)$ & 1.0 \\
\hline High & $97(35.7)$ & $175(64.9)$ & $0.88(0.63-1.23)$ & $95(54.0)$ & $81(46.0)$ & $1.45(0.91-2.34)$ \\
\hline \multicolumn{7}{|l|}{ Risky behaviour } \\
\hline Low & $108(49.1)$ & $112(50.9)$ & 1.0 & $69(79.3)$ & $18(20.7)$ & 1.0 \\
\hline High & $120(31.0)$ & $267(69.0)$ & $2.14(1.52-3.01)$ & $102(47.9)$ & $111(52.1)$ & $4.17(2.32-7.48)$ \\
\hline \multicolumn{7}{|l|}{ Family conflict } \\
\hline Low & $94(42.7)$ & $126(57.3)$ & 1.0 & $60(65.9)$ & $31(34.1)$ & 1.0 \\
\hline High & $135(34.5)$ & $256(65.5)$ & $1.41(1.01-1.98)$ & $115(54.2)$ & $97(45.8)$ & $1.63(0.98-2.72)$ \\
\hline \multicolumn{7}{|l|}{ Attitude } \\
\hline Less positive & $75(44.6)$ & $93(55.4)$ & 1.0 & $44(67.7)$ & $21(32.3)$ & 1.0 \\
\hline More positive & $150(34.8)$ & $281(65.2)$ & $1.51(1.05-2.17)$ & $125(54.0)$ & $104(45.4)$ & $1.74(0.97-3.11)$ \\
\hline \multicolumn{7}{|l|}{ Self-efficacy } \\
\hline Low & $78(36.3)$ & $137(63.7)$ & 1.0 & $61(55.5)$ & $49(44.5)$ & 1.0 \\
\hline Medium & $100(39.2)$ & $155(60.7)$ & $0.96(0.58-1.60)$ & $70(58.3)$ & $50(41.7)$ & $0.90(0.46-1.73)$ \\
\hline High & $33(35.5)$ & $60(46.5)$ & $1.13(0.77-1.64)$ & $28(52.8)$ & $25(47.2)$ & $1.12(0.66-1.89)$ \\
\hline
\end{tabular}

$\mathrm{CI}=$ confidence interval; $\mathrm{OR}=$ odds ratio.

Bold numbers with $\mathrm{P}<0.05$.

Examination of the predisposing factors of smoking contemplation or maintenance and the high response rate make this study unique in gaining new insights. Knowledge obtained from this research delivers messages about the predisposing factors for waterpipe smoking initiation. In addition, the findings concerning the predisposing factors for smoking maintenance are novel. This may help public health practitioners and policy-makers to develop new strategies to reduce levels of susceptibility.

However, a few limitations are important to consider when interpreting these findings. First, because this study was based on cross-sectional data, causal relationships cannot be inferred. Second, multiple conditions that were not considered in the present study (such as culture, and access to and use of other tobacco products and illicit substances) may affect different responses in relation to students' intention to start or maintain smoking in the future. Third, we did not collect information about all model domains. Future comprehensive prospective studies with updated data on cigarette and waterpipe smoking are recommended to assess the causal relationships between predisposing factors and smoking susceptibility. Finally the low number of questions for assessing some risk factors, such as risky behaviour or family conflict, could also be a limitation. A potential recommendation could be to develop further understanding of risky behaviour and family conflict and how they correlate with smoking.

\section{Conclusion}

The present study would be a good starting point for developing a risk prediction model, using identified risk 


\begin{tabular}{|c|c|c|c|c|}
\hline & \multicolumn{2}{|c|}{ Contemplation } & \multicolumn{2}{|c|}{ Maintenance } \\
\hline & Cigarette & Waterpipe & Cigarette & Waterpipe \\
\hline Depression & $1.96(1.41-2.72)$ & $1.09(0.89-1.33)$ & $1.49(0.83-2.68)$ & $0.87(0.58-1.31)$ \\
\hline Risky behaviour & $2.13(1.51-2.94)$ & $1.49(1.22-1.85)$ & $3.70(1.85-7.14)$ & $1.89(1.33-3.03)$ \\
\hline Family conflict & $1.87(1.38-2.53)$ & $1.53(1.24-1.88)$ & $1.10(0.59-2.05)$ & $1.25(0.83-1.89)$ \\
\hline $\begin{array}{l}\text { More positive attitude to smoking } \\
\text { acceptability }\end{array}$ & $2.12(1.51-2.97)$ & $1.72(1.41-2.10)$ & $1.46(0.73-2.91)$ & $1.57(1.03-2.40)$ \\
\hline \multicolumn{5}{|l|}{ Self-efficacy } \\
\hline Low & 1 & 1 & 1 & 1 \\
\hline Medium & $0.75(0.41-0.80)$ & $0.78(0.61-0.96)$ & $1.46(0.78-2.73)$ & $1.47(0.95-2.26)$ \\
\hline High & $0.47(0.29-0.85)$ & $0.79(0.94-1.70)$ & $0.86(0.39-1.93)$ & $1.14(0.62-2.09)$ \\
\hline Log likelihood & 1297.065 & 2713.739 & 1324.466 & 2794.327 \\
\hline $\mathbf{R} 2$ & 0.35 & 0.38 & 0.36 & 0.38 \\
\hline
\end{tabular}

Odds ratios adjusted for age, sex, parental education and smoking.

Bold numbers with $\mathrm{P}<0.05$.

factors for smoking contemplation and maintenance. Healthcare providers may benefit from such a model in targeting at-risk adolescents for prevention programmes. Preventive measurements might address adolescent psychological states, attitude to smoking acceptability, and above all, risky behaviour, and should be initiated for school-aged and early adolescents. Different approaches should be adopted to tackle different factors associated with cigarette and waterpipe smoking contemplation and maintenance.

\section{Acknowledgements}

Special thanks to all students who took part in this study. The study was approved by the Ethics Committee of Isfahan University of Medical Science.

Funding: None.

Competing interests: None declared.

\section{Facteurs associés à l'intention et au maintien du tabagisme chez les adolescents iraniens}

\section{Résumé}

Contexte: On dispose de peu de données sur les facteurs contribuant à l'initiation de la consommation de tabac par cigarette ou pipe à eau, et aucune étude antérieure n'a examiné les facteurs associés au maintien du tabagisme par pipe à eau.

Objectif : La présente étude visait à déterminer quels étaient les facteurs associés à l'initiation de la consommation de tabac par cigarette ou pipe à eau et au maintien de ce tabagisme chez les adolescents iraniens.

Méthodes : Des facteurs tels que la dépression, les comportements à risque, les conflits familiaux, l'attitude concernant l'acceptabilité du tabagisme et l'efficacité personnelle ont été examinés à l'aide d'un questionnaire distribué à 5500 adolescents qui étaient au stade de l'intention ou du maintien du tabagisme.

Résultats : Les adolescents souffrant de dépression avaient quasiment deux fois plus de probabilités [intervalle de confiance (IC) à $95 \%$ : 1,41-2,72] d'envisager le tabagisme par cigarettes. Pour les adolescents adeptes des comportements à risque, la probabilité liée à l'intention de tabagisme par cigarettes et par pipe à eau (hookah) était de 2,13 (IC à 95 \%: 1,51$2,94)$ et $1,49(1,22-1,85)$ respectivement. Pour les adolescents concernés par des conflits familiaux, cette même probabilité était de 1,87 (IC à $95 \%$ : 1,38-2,53) et 1,53 respectivement, et elle était de 2,12 IC à 95\%: 1,51-2,97) et 1,72 respectivement pour les étudiants qui faisaient montre d'une attitude plus positive concernant l'acceptabilité du tabagisme. Une meilleure efficacité personnelle était associée à une moins forte intention de tabagisme par cigarette et par pipe à eau. Le comportement à risque était associé au maintien du tabagisme. Une attitude plus positive concernant l'acceptabilité du tabagisme était davantage associée au maintien du tabagisme par pipe à eau (odds ratio = 1,7 IC à 95 \%: 1,03-2,40).

Conclusion: La dépression, l'attitude concernant l'acceptabilité du tabagisme et le comportement à risque sont des facteurs associés à l'intention et au maintien du tabagisme. 


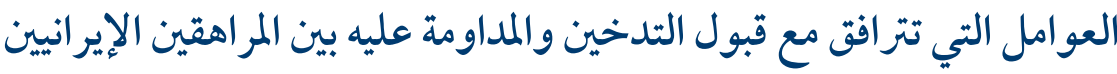

حميد رضا روح افزا، راضية اميدي، طاهرة علينيا، كمال حيدري، غلا محسين محمد-شافعي، مريد جابري فر، معصومة صادقي، وسيم مازياك

الخلفية: تندر الدلائل حول العوامل التي تُسهم في قبول تدخين السجائر والشيشة، ولا توجد أي دراسة سابقة حول العوامل المرتبطة بالمداومة على الشيشة. الهدف: هدفت هذه الدراسة إلى تحديد العو امل المرتبطة بقبول تدخين السجائر والشيشة والمداومة عليه لدى المراهقين الإير انيين.

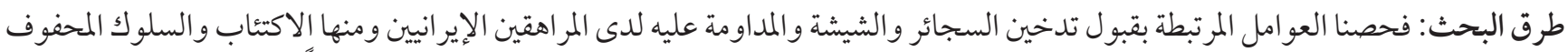

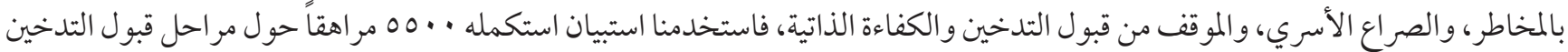
أو المداومة عليه.

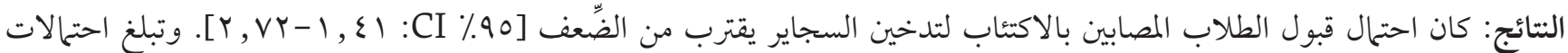

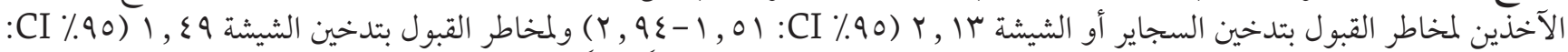

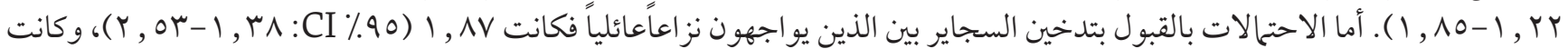

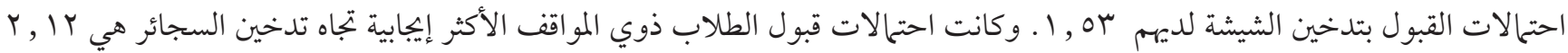

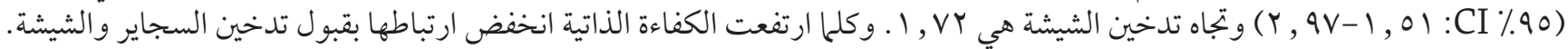

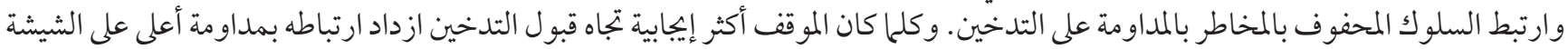
( $(r, \varepsilon \cdot-1, \cdot r: C I \%$. 90$)(r, \varepsilon-1, \cdot r: C I ; 1,0 V=O R)$ الاستتاج: إن الاكتئاب و الموقف من قبول التدخين والسلوك المحفوف بالمخاطر هي العوامل المرتبطة بقبول التدخين وبالمداومة عليه.

\section{References}

1. Gritz ER, Prokhorov AV, Hudmon KS, Mullin Jones M, Rosenblum C, Chang CC, et al. Predictors of susceptibility to smoking and ever smoking: a longitudinal study in a triethnic sample of adolescents. Nicotine Tob Res. 2003 Aug;5(4):493-506. https://doi. org/10.1080/1462220031000118568 PMID:12959787

2. Pierce JP, Choi WS, Gilpin EA, Farkas AJ, Merritt RK. Validation of susceptibility as a predictor of which adolescents take up smoking in the United States. Health Psychol. 1996 Sep;15(5):355-61. https://doi.org/10.1037/0278-6133.15.5.355 PMID:8891714

3. Unger JB, Johnson CA, Stoddard JL, Nezami E, Chou CP. Identification of adolescents at risk for smoking initiation: validation of a measure of susceptibility. Addict Behav. 1997 Jan-Feb;22(1):81-91. https://doi.org/10.1016/0306-4603(95)00107-7 PMID:9022874

4. Gilpin EA, Emery S, White MM, Pierce JP. Changes in youth smoking participation in California in the 1990s. Cancer Causes Control. 2003 Dec;14(10):985-93. https://doi.org/10.1023/B:CACO.0000007971.36237.a5 PMID:14750538

5. Tyas SL, Pederson LL. Psychosocial factors related to adolescent smoking: a critical review of the literature. Tob Control. 1998 Winter;7(4):409-20. https://doi.org/10.1136/tc.7.4.409 PMID:10093176

6. Roohafza H, Shahnam M, Zolfaghari B, Tavassoli A, Sadeghi M, Toloei H, et al. Stress level and smoking status in central iran: isfahan healthy heart program. ARYA Atheroscler. 2011 Winter;6(4):144-8. PMID:22577433

7. Perkins KA, Parzynski C, Mercincavage M, Conklin CA, Fonte CA. Is self-efficacy for smoking abstinence a cause of, or a reflection on, smoking behavior change? Exp Clin Psychopharmacol. 2012 Feb;20(1):56-62. https://doi.org/10.1037/a0025482 PMID:21910550

8. Chang FC, Lee CM, Lai HR, Chiang JT, Lee PH, Chen WJ. Social influences and self-efficacy as predictors of youth smoking initiation and cessation: a 3-year longitudinal study of vocational high school students in Taiwan. Addiction. 2006 Nov;101(11):164555. https://doi.org/10.1111/j.1360-0443.2006.01607.x PMID:17034445

9. Ulgen H, Ozturk C, Armstrong M. Effect of self-efficacy on Turkish children's perceptions of the advantages/disadvantages of smoking. Asian Pac J Cancer Prev. 2012;13(3):795-8. https://doi.org/10.7314/APJCP.2012.13.3.795 PMID:22631650

10. Ellickson PL, Tucker JS, Klein DJ. High-risk behaviors associated with early smoking: results from a 5-year follow-up. J Adolesc Health. 2001 Jun;28(6):465-73. https://doi.org/10.1016/S1054-139X(oo)00202-o PMID:11377990

11. Roohafza H, Sadeghi M, Shahnam M, Bahonar A, Sarafzadegan N. Perceived factors related to cigarette and waterpipe (ghelyan) initiation and maintenance in university students of Iran. Int J Public Health. 2011 Apr;56(2):175-80. https://doi.org/10.1007/ s00038-009-0107-x PMID:20020176

12. Wongpakaran T, Wongpakaran N, Boripuntakul T. Symptom checklist-9o (SCL-90) in a Thai sample. J Med Assoc Thai. 2011 Sep;94(9):1141-9. PMID:21970206

13. Distefan JM, Gilpin EA, Choi WS, Pierce JP. Parental influences predict adolescent smoking in the United States, 1989-1993. J Adolesc Health. 1998 Jun;22(6):466-74. https://doi.org/10.1016/S1054-139X(98)00013-5 PMID:9627817 
14. Brown RA, Lewinsohn PM, Seeley JR, Wagner EF. Cigarette smoking, major depression, and other psychiatric disorders among adolescents. J Am Acad Child Adolesc Psychiatry. 1996 Dec;35(12):1602-10. https://doi.org/10.1097/00004583-199612000-00011 PMID:8973066

15. Breslau N, Peterson EL, Schultz LR, Chilcoat HD, Andreski P. Major depression and stages of smoking. A longitudinal investigation. Arch Gen Psychiatry. 1998 Feb;55(2):161-6. https://doi.org/10.1001/archpsyc.55.2.161 PMID:9477930

16. Minnix JA, Blalock JA, Marani S, Prokhorov AV, Cinciripini PM. Self-efficacy mediates the effect of depression on smoking susceptibility in adolescents. Nicotine Tob Res. 2011 Aug;13(8):699-705. https://doi.org/10.1093/ntr/ntro61 PMID:21482619

17. Islam SM, Johnson CA. Influence of known psychosocial smoking risk factors on Egyptian adolescents' cigarette smoking behavior. Health Promot Int. 2005 Jun;20(2):135-45. https://doi.org/10.1093/heapro/dah604 PMID:15722365

18. Hill KG, Hawkins JD, Catalano RF, Abbott RD, Guo J. Family influences on the risk of daily smoking initiation. J Adolesc Health. 2005 Sep;37(3):202-10. https://doi.org/10.1016/j.jadohealth.2004.08.014 PMID:16109339

19. Yang WS, Leatherdale ST, Ahmed R. Smoking susceptibility among never-smokers: data from the 2006-07 National Youth Smoking Survey. Can J Public Health. 2011 Jul-Aug;102(4):254-7. PMID:21913578

20. Odukoya OO, Odeyemi KA, Oyeyemi AS, Upadhyay RP. Determinants of smoking initiation and susceptibility to future smoking among school-going adolescents in Lagos State, Nigeria. Asian Pac J Cancer Prev. 2013;14(3):1747-53. https://doi.org/10.7314/APJCP.2013.14.3.1747 PMID:23679268

21. Roohafza H, Sadeghi M, Shahnam M, Shokouh P, Teimori S, Amirpour A, et al. Social norms of cigarette and hookah smokers in Iranian universities. ARYA Atheroscler. 2013 Jan;9(1):45-50. PMID:23696759

22. Donovan JE, Jessor R, Costa FM. Adolescent health behavior and conventionality-unconventionality: an extension of problem-behavior theory. Health Psychol. 1991;10(1):52-61. https://doi.org/10.1037/0278-6133.10.1.52 PMID:2026131

23. Mazur J, Dzielska A, Małkowska-Szkutnik A. [The relationship between tobacco smoking and risk behaviour syndrome among 15-year-old adolescents in Poland and other European countries]. Przegl Lek. 2009;66(10):768-72 (in Polish). PMID:20301933

24. Yu M, Nebbitt VE, Lombe M, Pitner RO, Salas-Wright CP. Understanding tobacco use among urban African American adolescents living in public housing communities: a test of problem behavior theory. Addict Behav. 2012 Aug;37(8):978-81. https://doi. org/10.1016/j.addbeh.2012.03.023 PMID:22503437

25. Maziak W, Eissenberg T, Ward KD. Patterns of waterpipe use and dependence: implications for intervention development. Pharmacol Biochem Behav. 2005 Jan;80(1):173-9. https://doi.org/10.1016/j.pbb.2004.10.026 PMID:15652393

26. Tamim H, Terro A, Kassem H, Ghazi A, Khamis TA, Hay MM, et al. Tobacco use by university students, Lebanon, 2001. Addiction. 2003 Jul;98(7):933-9. https://doi.org/10.1046/j.1360-0443.2003.00413.x PMID:12814499 